\title{
Reading in Two Languages: Evidence from Miscue Analysis
}

\begin{abstract}
This paper reports on the oral reading of five grade 2 to 6 isiXhosa (L1) speakers reading isiXhosa (L1) and English (L2) texts. It examines the readers' oral reading miscues (or errors) to understand the extent to which these miscues constitute a language or a literacy problem in this group of readers. Conclusions are that (a) these readers read better in isiXhosa than in English; (b) they are not reading as well as they could be reading in isiXhosa; (c) isiXhosa reading difficulties appear to be related to poor teaching of literacy; (d) while English reading difficulties appear to be related to both poor teaching of literacy and to low levels of language proficiency in English, this is related to classroom practices but is also independent of it.
\end{abstract}

Keywords: Reading, reading miscues, language, literacy, isiXhosa, English.

Brian Lwazi Ramadiro, University of Fort Hare.E-mail: bramadiro@ufh.ac.za

South African Journal of Childhood Education | 2012 2(2): 74-93 | ISSN: 2223-7674 | ๑ UJ 


\section{Introduction}

Language and literacy are subjects of research in many areas of education and social science research. The specific relationship between language and literacy addressed in this study is that of the relationship between oral language proficiency and reading proficiency. The study examines the semantic, syntactic and graphophonic cueing systems used during oral reading (Goodman, 2003 [1994]) by five grade 2 to grade 6 Eastern Cape isiXhosa primary school readers, reading isiXhosa (First Language/L1) and English (Second Language/L2) texts. Comparing the patterns of use of these cueing systems can reveal how readers approach the task of reading (Beatty \& Care, 2009, p. 226) in the Home Language (L1) and First Additional Language (L2) and suggest implications for teaching and learning. The aim of the study is to contribute to a better understanding of the complex relationship that exists between language and literacy in a highly unequal 'linguistic market' (Bourdieu, 1991, pp. 37-39), and to provide nuance to current debates about the need to strengthen the use of African languages as languages of teaching and learning, alongside English, in the Foundation Phase and to extend their use in this capacity to the Intermediate Phase.

Although the focus of this paper is the psychological and linguistic aspects of reading, its point of departure is that the psycho-linguistic aspects of reading are shaped by and interact with larger societal factors that inform contexts, opportunities and purposes of learning. These include demographic factors (Sirin, 2005; van der Berg \& Burger, 2003), sociolinguistic factors (Heugh, 2003) and factors operating at the school-level (Adams, 1990; Chall, Jacobs, \& Baldwin, 1990; Cummins, 2001). In a divided and unequal society like South Africa, these societal factors position readers in different but specific ways in relation to the acquisition and use of literacy. What people read, if indeed they read, how often, how much, where, with whom, in what language(s), and, what they ultimately 'get' from reading is enabled or constrained by larger societal factors.

\section{Miscue analysis}

Goodman, Watson \& Burke (2005, p. 3) define a miscue as 'a place [in a text] in which a reader's observed response (OR) does not match the expected response (ER)'. In non-technical usage a miscue is an 'error' that is produced during oral reading. Miscues can be of several kinds and include word substitutions, insertions, omissions and reversals (Goodman, Watson \& Burke, 2005, p. 63-75). Over the past 45 years miscue studies have been conducted into a range of linguistic groups, such as speakers of non-standard dialects of English, second and foreign language speakers of English, alphabetic languages other than English, and non-alphabetic (written) languages (see, for example, Flurkey, Paulson \& Goodman, 2008). Applications of miscue analysis include pre-service and in-service teacher training, materials development, one-to-one reading instruction, whole class reading instruction, as well as special and remedial education (see essays in Goodman, 1979; Marek \& Edelsky, 1999). 
Miscue analysis makes three basic claims: 1 ) reading is a linguistic process (Goodman, 2003 [1994], p. 2) reading miscues are produced by the same processes that underpin correct/successful reading (Goodman, 1975), p. 3) reading is a psycholinguistic guessing game in which three language cueing systems are used to make sense of text, viz. the graphophonic, syntactic and semantic cueing systems (Goodman, 1976; Goodman \& Goodman, 2004). Each of these claims is discussed below.

Reading is a socio-psycholinguistic process that involves a writer, a text and a reader (for a similar conception of literacy see Rosenblatt, 2004). A 'writer creates a text to represent meaning' (Goodman, 2003 [1994], p. 4). Writers write for real social reasons, such as to persuade, inform, entertain or record. In order to increase the chances of their messages being understood by readers, writers encode their messages in vocabulary, language patterns, text patterns and genres fit for the purpose. Writers cannot write exhaustive texts. They expect readers to use their own knowledge of the world, language and context of the text to infer implicit meanings of a text. Readers bring their knowledge, experiences and interests about language and reading to every act of reading. In every act of reading, readers try to figure out why a writer wrote the text, to identify text patterns, wording, and assumptions the writer has made about shared knowledge. Reading is, therefore, an active sociopsycholinguistic process, whose 'meaning is in the reader and the writer, not in the text' (Goodman, 2003 [1994], p. 4).

Goodman's (2003 [1994]) second claim is that oral reading errors are produced by the same processes that underpin correct or successful reading. Goodman prefers the word 'miscues' over 'error' for three reasons. First, 'error' has a negative connotation suggesting that all 'errors' are bad and must be eliminated from reading (Wilde, 2000.p. 2). Goodman would argue that this gives the wrong impression that 'proficient reading' is the same as 'error free' reading, and, therefore, that less proficient readers should be trained to perform error free reading. He argues, in contrast, that all readers make 'errors'. All readers substitute, insert or omit words during oral or silent reading. A chief difference between 'errors' of proficient and less proficient readers is that, overall, proficient readers' miscues are syntactically and semantically acceptable within the sentence or text, and if they are not, proficient readers correct themselves. Second, 'errors' are not random but have causes in the same way that correct responses do. Goodman's specific contention is that errors, like expected responses, arise from a reader's attempt to make sense of text. Thus, when a reader miscues, she or he is still using the same language cueing systems as when she or he makes a correct response. Third, the word 'mis-cue' underlines the claim that readers use 'multiple cueing systems' of written language to read (Wilde, 2000, p. 2). Simultaneous, flexible and integrative use of graphophonic, semantic and syntactic cueing systems is necessary for successful reading to take place (Goodman \& Goodman, 2004).

Goodman's third claim is that reading is a psycholinguistic 'guessing game' in which graphophonic, syntactic cueing systems are used to process (alphabetic) texts (Goodman, 2003 [1967]). As alphabetic languages, this claim is applicable both 
to English and isiXhosa texts and readers. Goodman, Watson \& Burke (2005,pp. 3036) describe the three cueing systems as follows. The graphophonic cueing system governs the relationship between orthography (letters of the alphabet, conventions of spelling, punctuation and word boundaries, and the phonological system). The syntactic system is the lexico-grammar (vocabulary and grammatical rules). This includes naturally acquired or formally taught knowledge about word classes (including noun classes in isiXhosa), tenses and number. The semantic cueing system has to do with meanings of words and phrases and how they relate to each other, and in turn how this knowledge relates to language use. Goodman (2003,p. 32) borrows from Michael Halliday the idea that grammar is about wording and rules for word and sentence combination beyond the sentence. Goodman (1996) claims that search for meaning is the only goal of reading and the semantic cueing system is the single most important system. Readers use all cueing systems during reading; the distinction is that proficient readers rely more on the semantic system whereas the less proficient readers rely more on the graphophonic cueing system (Goodman \& Goodman, 2004).

\section{Criticisms of miscue analysis}

Miscue analysis has been the subject of criticism at the conceptual (e.g., Mosenthal, 1976/77; Stanovich, 2000), empirical (e.g., Stanovich, 2004; Beatty \& Care, 2009), and pedagogical levels (e.g. Adams, 1990; Wren, 2008). Criticism of miscue analysis is often framed within a distinction that is made between 'top-down' and 'bottom-up' models of reading. Pushing the 'top-down/bottom-up' metaphor to the limit, Freeman \& Freeman (2003,p. 37) go so far as to claim that there are essentially two views of reading, a word recognition view (bottom-up model) and a socio-psycholinguistic view (top-down model). According to Stanovich (2000,p. 5), top-down models like miscue analysis, 'strongly emphasize the contribution of expectancies and contextual information. The word recognition process [is] thought to be heavily penetrated by background knowledge and higher level cognitive expectancies'. Bottom-up models, on the other hand, suggest that reading is a 'bottom-up, part-to-whole process and should be taught as incremental skill-building. In this view, the reader moves from sounding out and identifying the meanings of words to understanding sentences, then paragraphs' (Braunger \& Lewis, 2006, p. 9). One proposal to reconcile the two models of reading is Stanovich's (2000, pp. 21-43) Interactive-compensatory model.

At least three specific common criticisms of miscue analysis are important for this paper. The first is about the place of the graphophonic cueing system in the reading process relative to the syntactic and semantic systems. Goodman \& Goodman (2004, p. 630) make clarify their view of the place of graphophonics in their model of the reading process. They argue, 'Our research demonstrates that the least proficient readers we studied in the $6^{\text {th }}, 8^{\text {th }}$ and $10^{\text {th }}$ grades use graphic information more than the most proficient readers.' Stanovich (2004, p. 465) contests this claim. First, it is not that good readers are less reliant on visual information but that they expend less capacity to process visual information fully. Second, the reason they expend less capacity is not because they rely on context but because their 'stimulus-analysis 
mechanisms are so powerful.' In addition, a recent Australian study of reading miscues of a hundred children between aged 5-8 years (Beatty \& Care, 2009, p. 239) found that 'average' and 'above average' readers are likely to rely more on graphophonic cues than 'below average' readers when reading an unfamiliar text.

Second, researchers have criticised Goodman's formulation of the relative contribution of the three cueing systems to meaning-making (comprehension) (Adams, 1990). Miscue analysis predicts that proficient readers rely more on semantic cues and less on graphophonic cues to read unfamiliar texts. Adams (1990) accepts that all three cueing systems contribute to comprehension, but that the graphophonic system is fundamental, because it is print on the page that supplies the perceptual data on which comprehension is dependent (Also see NICHHD, 2000, p. 4-11; Rand Study Group, 2004).

A final criticism of miscue analysis is that it could mislead users, teachers in particular, into making unsound pedagogical decisions (Mckenna \& Picard, 2006). The claim is that miscue analysis underplays the role of graphophonics in the reading process. An often unstated assumption of this criticism is that all users of miscue analysis are uncritical adherents of the 'whole language approach' and see only a marginal role for graphophonics in the reading process. Critics argue it is just the wrong thing to encourage children to use contextual cues, illustrations, syntax or semantics to figure out words and text they don't know.

Below is an outline of how researchers who are indebted to miscue analysis (e.g., Moustafa, 1997) or those who defend some of its assumptions (e.g. Cummins, 2003) would approach a response to these criticisms. In the first instance, they would argue that knowledge of graphophonics is essential to all beginning readers. The issue in dispute is: how do beginning readers acquire knowledge of graphophonics? Because there are multiple pathways to acquire phonemic and basic graphophonic knowledge before entering school or soon thereafter, ensuring that all children acquire this knowledge is more important than how they acquire it (Cummins, 2003). Second, some strands of the 'whole language approach,' exemplified by Moustafa (1997,p. 92), hold the view that graphophonics instruction in the early grades can be 'systematic, explicit and extensive' by working 'from whole to parts, from whole texts, to words, to word parts'. There is no necessary connection between a 'top-down' reading model and marginalization of graphophonics in reading instruction. In any event, 'it is not whether whole-word or phonics is "right" or "effective", but when, for whom' (Alexander \& Fox, 2004, p. 59). Third, reading comprehension, the very reason why phonics instruction takes place in the first place, is overwhelmingly correlated with extensive reading because readers learn to read by reading and not only by learning abstract graphophonic rules (Krashen, 2003).

\section{The current study}

The study examines oral language proficiency and reading proficiency. The assumption of the study is that, all things being equal, readers' superior oral language proficiency 
in isiXhosa (L1) translates into superior reading in the L1. To this end, the study examines and analyses readers' oral miscues to determine if the readers' miscues are graphophonically, syntactically and semantically acceptable in the L1 and L2. The following questions are explored:

1. Do readers' miscues retain grammaticality in isiXhosa (L1) and English (L2)?

2. Do readers' miscues retain textual meaning (are the readers' miscues semantically acceptable) in the L1 and L2?

3. Are readers' miscues graphophonically acceptable in the L1 and L2?

4. Are readers using all three cueing systems in an effective manner?

\section{Methods}

Table 1: Readers' biographical and reading data

\begin{tabular}{|c|c|c|c|c|c|c|}
\hline 1 & 2 & 3 & 4 & 5 & 6 & 7 \\
\hline Reader & Age & Sex & Grade & Text Difficulty & $\begin{array}{c}\text { Language } \\
\text { of text }\end{array}$ & Miscues \\
\hline \multirow[t]{3}{*}{ Khanyisile } & \multirow[t]{3}{*}{8} & \multirow[t]{3}{*}{ Male } & \multirow[t]{3}{*}{2} & Grade 2 & isiXhosa & 24 \\
\hline & & & & Grade 3 & isiXhosa & 4 \\
\hline & & & & Pre-primer & English & 2 \\
\hline \multicolumn{6}{|l|}{ Sub-Total } & 30 \\
\hline \multirow[t]{3}{*}{ Sbusiso } & \multirow[t]{3}{*}{9} & \multirow[t]{3}{*}{ Male } & \multirow[t]{3}{*}{3} & Grade 2 & isiXhosa & 14 \\
\hline & & & & Grade 3 & isiXhosa & 24 \\
\hline & & & & Pre-primer & English & 4 \\
\hline \multicolumn{6}{|l|}{ Sub-Total } & 42 \\
\hline \multirow[t]{4}{*}{ Nobuntu } & \multirow[t]{4}{*}{10} & \multirow[t]{4}{*}{ Female } & \multirow[t]{4}{*}{4} & Grade 3 & isiXhosa & 6 \\
\hline & & & & Grade 4 & isiXhosa & 15 \\
\hline & & & & Grade 3 & English & 17 \\
\hline & & & & Grade 4 & English & 21 \\
\hline \multicolumn{6}{|l|}{ Sub-Total } & 59 \\
\hline \multirow[t]{4}{*}{ Mihlali } & \multirow[t]{4}{*}{11} & \multirow[t]{4}{*}{ Female } & \multirow[t]{4}{*}{5} & Grade 4 & isiXhosa & 23 \\
\hline & & & & Grade 5 & isiXhosa & 25 \\
\hline & & & & Grade 4 & English & 31 \\
\hline & & & & Grade 5 & English & 26 \\
\hline \multicolumn{6}{|l|}{ Sub-Total } & 105 \\
\hline \multirow[t]{5}{*}{ Sindi } & \multirow[t]{5}{*}{13} & \multirow[t]{5}{*}{ Female } & \multirow[t]{5}{*}{6} & Grade 4 & isiXhosa & 26 \\
\hline & & & & Grade 5 & isiXhosa & 20 \\
\hline & & & & Grade $4(\mathrm{~N})$ & English & 31 \\
\hline & & & & Grade 4 (E) & English & 32 \\
\hline & & & & Grade 5 & English & 26 \\
\hline \multicolumn{6}{|l|}{ Sub-Total } & 135 \\
\hline
\end{tabular}




\begin{tabular}{|c|c|c|c|c|c|c|}
\hline 1 & 2 & 3 & 4 & 5 & 6 & 7 \\
\hline Reader & Age & Sex & Grade & Text Difficulty & $\begin{array}{c}\text { Language } \\
\text { of text }\end{array}$ & Miscues \\
\hline \multirow[t]{4}{*}{ Sisipho } & \multirow[t]{4}{*}{ Adult } & \multirow[t]{4}{*}{ Female } & \multirow{4}{*}{$\begin{array}{l}\text { Post- } \\
\text { school }\end{array}$} & Grade 2 & isiXhosa & 1 \\
\hline & & & & Grade 3 & isiXhosa & 4 \\
\hline & & & & Grade 4 & isiXhosa & 5 \\
\hline & & & & Grade 5 & isiXhosa & 12 \\
\hline \multicolumn{6}{|l|}{ Sub-Total } & 22 \\
\hline \multirow[t]{4}{*}{ Ayanda } & \multirow[t]{4}{*}{ Adult } & \multirow[t]{4}{*}{ Female } & \multirow{4}{*}{$\begin{array}{l}\text { Post- } \\
\text { school }\end{array}$} & Grade 2 & isiXhosa & 1 \\
\hline & & & & Grade 3 & isiXhosa & 1 \\
\hline & & & & Grade 4 & isiXhosa & 5 \\
\hline & & & & Grade 5 & isiXhosa & 15 \\
\hline \multicolumn{6}{|l|}{ Sub-Total } & 22 \\
\hline \multicolumn{6}{|l|}{ TOTAL } & 415 \\
\hline
\end{tabular}

\section{Participants}

There are a total of 7 participants in this study, 5 young readers and 2 adult readers (Column 1). The young readers are 3 girls and 2 boys (Column 3 ) in grades 2 through 6 (Column 4). The group's age ranges between 8 to 13 years (Column 2). The child readers attend the same small but relatively well-resourced farm school in the Eastern Cape. All children use mainly isiXhosa at home, in school and in the community. One child reported that one of her parents speaks and reads mainly in Afrikaans, although the child herself used mainly isiXhosa. The adult readers are two university educated females and L1 speakers of isiXhosa. The adult readers were included in the study primarily to establish an indicative benchmark upon which to base a miscue analysis, currently not available for isiXhosa texts. All names are pseudonyms.

\section{Selection}

Child readers were selected on recommendation by their class teachers. The brief to teachers was to identify the strongest readers in class present on the day of the reading assessment. Adult readers were identified by the researcher on the basis of availability and willingness to take part in the study and because of their competence in isiXhosa.

\section{Materials}

Each child reader reads 2 authentic isiXhosa and 2 English texts (Column 5 and 6), except for Sindi (grade 6) who read 3 English texts because she appeared to breeze through her initial English text. The general approach was to build readers' confidence by asking them to begin by reading texts at or below their reading level. Miscue analysis requires (Goodman, Watson \& Burke, 2005, p. 46-50) that readers read 1) complete authentic/connected texts, 2) new texts, 3) texts they are likely be interested in, 4) texts of sufficient length, and 5) texts that are challenging enough so that readers' 
strategies for dealing with the unknown words are observable but not too difficult to result in frustration. Reading was stopped any time readers wished to stop or when they were observed to have serious difficulty with a text. Note with Khanysile (grade 2) and Sbusiso (grade 3) administration of English texts began much lower than their official grade level as per the Qualitative Reading Inventory (Leslie \& Caldwell, 2006). A conversation with these readers indicated that their knowledge of English was lower than their official grade level might suggest. IsiXhosa texts were selected from the school's library collection and English texts were taken from the Qualitative Reading Inventory (Leslie \& Caldwell, 2006). The advantage of using graded passages from the Qualitative Reading Inventory is that they have established norms for readability/ reading level, accuracy and reading rate (speed). There are currently no equivalent normative tools in isiXhosa. In order to address this, the two adult readers' miscues, accuracy and reading rate scores have been used as an indicative benchmark against which to compare young readers' oral reading miscues in isiXhosa. Readers are urged, therefore, to treat comparisons between reading behaviours of adult proficient readers and child readers with the necessary circumspection.

\section{Data production procedures}

The miscue data reported in this study forms part of a larger and multidimensional data base. The data was produced in the following order:

- $\quad$ Step 1 - Reading Interview: Administration of a modified and translated version of Burke Reading Interview (Goodman, Watson \& Burke, 2005, pp. 179-182). This was used to get a sense of the readers' conception and experiences of reading (Child readers).

- $\quad$ Step 2 - Reading isiXhosa Texts: Oral reading and marking of isiXhosa and English text typescripts. All readings were audio recorded and some were also video recorded (Child and adult readers).

- Step 3 - Retelling isiXhosa Texts: Retelling of isiXhosa texts after each reading (Child readers).

- $\quad$ Step 4 - isiXhosa Writing: Readers write a short comparison passage in isiXhosa (Child readers).

- $\quad$ Step 5 - English Word Lists: Oral reading of English word lists. No oral reading word lists are available for isiXhosa (Child readers).

- $\quad$ Step 6 - Reading English Texts: Oral reading of English texts (Child readers).

- $\quad$ Step 7 - Retelling English Texts: Retelling of English texts after each reading (Child readers).

- $\quad$ Step 8 - English Writing: Readers write a short comparison passage in English (Child readers). 


\section{Findings}

\section{Syntactic/grammatical acceptability}

Analysis of syntactic miscues seeks to establish whether readers' miscues retain the grammar of the original text. Miscues that retain text grammar are indicative of readers' success in integrating knowledge or intuitions about language in the process of reading. Fries' (2008) practice of analysing 'same grammar' apart from 'total grammatically acceptable' miscues is followed here. 'Same grammar' miscues are those miscues that fully and unambiguously retain grammaticality of a text in the context of both the sentence and the text as a whole. 'Total grammatically acceptable' miscues include 'same grammar' and 'partially grammatical' miscues. 'Partially grammatical' miscues are those miscues acceptable only in the context of the sentence up to and including the miscue but not acceptable in the context of the text as a whole (Goodman, Watson, \& Burke, 2005, p 136). Given isiXhosa language dominance of this group of readers, it is expected that data will show that a greater proportion of readers' isiXhosa (L1) miscues retain 'same grammar' compared to the English (L2).

Table 2: Same Grammar Miscues Across English and isiXhosa Texts

\begin{tabular}{|l|c|c|c|c|c|} 
& $\begin{array}{c}\text { Khanyisile } \\
\text { Gr2 }\end{array}$ & $\begin{array}{c}\text { Sbusiso } \\
\text { Gr3 }\end{array}$ & $\begin{array}{c}\text { Nobuntu } \\
\text { Gr4 }\end{array}$ & $\begin{array}{c}\text { Mihlali } \\
\text { Gr5 }\end{array}$ & $\begin{array}{c}\text { Sindi } \\
\text { Gr6 }\end{array}$ \\
\hline isiXhosa & $1350 \%)$ & $7(18 \%)$ & $13(62 \%)$ & $25(52 \%)$ & $31(67 \%)$ \\
\hline English & $\mathrm{NI}$ & $\mathrm{NI}$ & $8(21 \%)$ & $13(23 \%)$ & $17(18 \%)$ \\
\hline
\end{tabular}

NB: not interpretable due to low levels

Table 2 shows that indeed readers' miscues retain 'same grammar' better in isiXhosa than English. IsiXhosa miscues that retain 'same grammar' are rather low considering that this is the readers' L1. Only $18 \%$ of Sbusiso's miscues retain 'same grammar' and up to $67 \%$ of Sindi's. The overall suggestion is that these readers are not that successful at integrating knowledge about isiXhosa language into their reading. Example 1 and 2 below illustrates how readers' isiXhosa miscues retain 'same grammar'.

\section{Example 1}

\section{Khanyisile, a grade 2 reader, reading a grade 2 isiXhosa text}

Original text: Athi uMona, 'Masimshiye lo xa engnamli (...) (Mona said, 'let's leave her behind if she doesn't have money')

Reader's text: Uthi uMona, 'Masimshiyeni lo xa engenamali' (Mona says, 'let's leave her behind if she doesn't have money') 


\section{Example 2}

\section{Sbusiso, a grade 3 reader, reading a grade 2 isiXhosa text}

Original text: 'Uthini?' (What did she/he say?)

Reader's text: 'Uthini? (What are you saying?)

In Example 1 Khanyisile makes two miscues. First he substitutes/uthi/ for /athi/. A subjectival concord /a-/ + verbal form /-thi/ is replaced by a subjectival concord / $\mathrm{u}-\mathrm{I}$ + verbal form /-thi/. Second, he substitutes /masimshiye/, a plural concord +verb form, for /masimshiyeni/, a plural concord + verb form. His miscues belong to the same grammatical category as the original words and retain 'same grammar,' while preserving the meaning of the original text. This is not the case with Sbusiso's miscue in Example 2. His miscue doesn't preserve meaning of the original text. The word / uthini/ looks (i.e., it is spelled) the same in the original text and the reader's text, but it is pronounced differently. In the original, text form is said with a rising-falling tone and it asks, 'What did she/he say?' And in the reader's form, it is said with a levelrising-falling tone and it asks the question, 'What are you saying? This miscue retains grammar, a question is substituted by a question, but the meaning of the text is altered. For comparison, examination of adult readers' miscues shows that almost all their miscues are fully grammatically acceptable. In fact, only one miscue produced by an adult was partially ungrammatical.

For English, a comparatively smaller proportion of miscues retain 'same grammar'. None of the Foundation Phase (grade 2 and 3) readers' English miscues retains 'same grammar'. The highest proportion of miscues in the group that preserve 'same grammar' in English are Mihlali's at 23\%, much worse than the isiXhosa miscues. Consider example 3 .

\section{Example 3}

\section{Sindi, a grade 6 reader, reading a grade 5 English text}

Original text: When Martin Luther King, Jr. was a boy, many laws would not allow black people to go to the same (...)

Reader's text: When Martin Luther King, Jr. was a boy, many laws would not allow back people to go to the same (...)

Example 3 is typical of the group's 'same grammar' miscues. Sindi read /back/ for / black/ replacing an adjective with a noun. This miscue would be grammatically unacceptable except that the reader corrected it. However, the correction appears to have been triggered less by the reader's awareness of a breakdown in grammar or meaning, than by awareness of a graphophonic mismatch between the text and the miscue. 
Table 3: Total grammatically acceptable miscues

\begin{tabular}{|l|l|l|l|l|l|}
\hline & \multicolumn{1}{|c|}{$\begin{array}{c}\text { Khanyisile } \\
\text { Gr2 }\end{array}$} & \multicolumn{1}{|c|}{$\begin{array}{c}\text { Sbusiso } \\
\text { Gr3 }\end{array}$} & $\begin{array}{c}\text { Nobuntu } \\
\text { Gr4 }\end{array}$ & \multicolumn{1}{|c|}{$\begin{array}{c}\text { Mihlali } \\
\text { Gr5 }\end{array}$} & \multicolumn{1}{|c|}{$\begin{array}{c}\text { Sindi } \\
\text { Gr6 }\end{array}$} \\
\hline & & & & & \\
\hline isiXhosa & $19(68 \%)$ & $15(39 \%)$ & $17(81 \%)$ & $36(75 \%)$ & $36(75 \%)$ \\
\hline English & $1(50 \%)$ & $2(50 \%)$ & $17(45 \%)$ & $32(56 \%)$ & $32(36 \%)$ \\
\hline
\end{tabular}

In order to get a more complete picture of readers' control of the grammatical cueing system, 'total grammatically acceptable' miscues are considered (see Table 3). From a 'total grammatically acceptable' point of view, the group is cast in a rather positive light, with Sbusiso being the exception. Khanyisile's isiXhosa 'total grammatically acceptable' miscues go up from $50 \%$ to $68 \%$, Sbusiso's from $18 \%$ to $39 \%$, Nobuntu's from $62 \%$ to $81 \%$, Mihlali's from $52 \%$ to $75 \%$, and Sindi's from $67 \%$ to $75 \%$. Because 'total grammatically miscues' are arrived at by including the 'partially grammatical' miscues, it is likely that readers' ability to get to the meaning of the text is impaired.

Adding together 'same grammar' and 'partially grammatical' miscues has a moderate effect on 'total grammatically acceptable' miscues in English. Khanyisile's and Sbusiso's 'total grammatically acceptable' miscues increase from $0 \%$ to $50 \%$, Nobuntu's from $21 \%$ to $45 \%$, Mihlali's from $23 \%$ to $56 \%$ and Sindi's from $18 \%$ to $36 \%$. Accounting for 'partially grammatical' miscues does improve the group's outlook. Note that Khanyisile's and Sbusiso's scores are not interpretable because they have produced so few miscues. There are at least two reasons behind the low number of miscues. The one is that the readers treated their English text as grammatical and semantic non-sense and for this reason focused their energies on correctly sounding out words on the page (graphophonics), and the other is that the two readers read only a short text each. For the rest of the group, English miscues that partially retain grammar tend to be those that make a minimal or superficial changes to grammar, like single word substitutions, resulting in plural forms or changes in word tense. Example 4 illustrates this point.

\section{Example 4}

\section{Mihlali, a grade 5 reader, reading a grade 4 English text}

Original text: But he never gave up.

Reader's text: But he never give up.

Strictly speaking, Mihlali's substituting the past tense verb 'gave' for the present tense 'give' results in an ungrammatical sequence. Taking account of the fact that Mihlali is a novice L2 user of English, it is more accurate to regard this miscue as partially grammatical, because from the point of view of this child the two forms of the verb are probably grammatically equivalent.

Overall, the readers' miscues retain grammaticality significantly better in isiXhosa than in English. The readers' relative grammatical strength in isiXhosa is just that, 
relative. In real terms, the low levels of miscues that retain grammaticality in isiXhosa suggest that beyond the problem of language per se, these children have not yet benefitted from strong enough literacy instruction to empower them to successfully integrate their own knowledge and intuitions of their (L1) home language into their reading process. It is also worrisome that the proportion of grammatically unacceptable isiXhosa miscues, in other words production of words that are grammatical non-sense, doesn't decrease as readers move up the grades. While further research is required, this again points to the hypothesis that current instructional strategies for literacy are unsuccessful at integrating reading with even L1 language proficiency.

\section{Semantic/meaning acceptability}

The route to meaning is through language. A miscue that is grammatically acceptable is not necessarily semantically acceptable. Grammaticality is a necessary condition for but not a guarantee of semantic acceptability. Examples 2 and 3 make this point. Examination of the adult isiXhosa 'same grammar' and 'retained meaning' miscues provides additional evidence for this view. Table 4 shows that all the adults' miscues are grammatically acceptable but that some of their miscues fail to retain sentence level and textual meaning. Keeping track of meaning during oral reading can be tough for adults too. It is only after 'retained meaning' and 'partial meaning loss' miscues are combined, as recommended by miscue methodology (Goodman, Watson \& Burke, 2005, p. 137), that all the adults' miscues are $100 \%$ semantically acceptable.

Table 4: Adult Readers: 'Retained meaning' and 'Partial meaning loss' Miscues

\begin{tabular}{|l|c|c|}
\hline & Sisipho & Ayanda \\
\hline Semantically Acceptable & $86 \%$ & $86 \%$ \\
\hline Partial Meaning Loss & $14 \%$ & $14 \%$ \\
\hline & $100 \%$ & $100 \%$ \\
\hline
\end{tabular}

Turning to the child readers, Table 5 shows, as expected, that a low proportion of grammatically acceptable miscues foreshadows a low proportion of semantically acceptable miscues. Comparison of Table 3 and 5 shows that, across readers and languages, semantically acceptable miscues are lower than grammatically acceptable miscues.

Table 5: 'Retained meaning' and 'Partial meaning loss' Miscues

\begin{tabular}{|l|c|c|c|c|c|} 
& $\begin{array}{c}\text { Khanyisile } \\
\text { Gr2 }\end{array}$ & $\begin{array}{c}\text { Sbusiso } \\
\text { Gr3 }\end{array}$ & $\begin{array}{c}\text { Nobuntu } \\
\text { Gr4 }\end{array}$ & $\begin{array}{c}\text { Mihlali } \\
\text { Gr5 }\end{array}$ & $\begin{array}{c}\text { Sindi } \\
\text { Gr6 }\end{array}$ \\
\hline isiXhosa & $16(57 \%)$ & $8(21 \%)$ & $12(57 \%)$ & $31(65 \%)$ & $33(72 \%)$ \\
\hline English & & & $13(34 \%)$ & $29(51 \%)$ & $30(34 \%)$ \\
\hline
\end{tabular}

Table 5 shows that isiXhosa miscues retain meaning better than English miscues, especially so for the Intermediate Phase readers. This is, however, not the case for 
English. Because of the relatively low proportion of grammatically and even lower number of semantically acceptable miscues, it is expected readers' retellings will show that readers struggle to retain the meaning of both isiXhosa and especially the English texts. The overall suggestion of the data up to this point is that readers are not successful at using grammatical and semantic cues to get to the meaning of texts. In other words, these readers are arguably (able to) pay(ing) little attention to grammatical 'well-formedness' of what they read and even less attention to its semantic 'sense'. Readers' retellings, which are not discussed in this paper, do in fact confirm severe loss of meaning in isiXhosa and especially so in English.

Example 5 below illustrates a 'grammatically acceptable' but 'semantically unacceptable' isiXhosa miscue. The possessive /wam/ (mine) is substituted with the / wakho/ (yours). This miscue has the effect of retaining 'same grammar' but changes sentence referent, its meaning, and potentially leading to a loss of meaning. This miscue was, however, corrected by the reader.

\section{Example 5}

\section{Khanyisile, a grade 2 reader, reading a grade 2 isiXhsoa text}

Original text: 'Uthi umama wam akanamali youkukusa kule ndewo beniza kuya kuyo" (My mom says she doesn't have money to take you where you were going)

Reader's text: 'Uthi umama wakho akanamali yokukusa kule ndawo beniza kuya kuyo" (Your mom says she doesn't have money to take you where you were going.)

Turning to English, Table 5 shows that only a small proportion of the readers' English miscues 'retain meaning'. In other words, a large proportion of the readers' English miscues are likely to lead to a loss of meaning. Predictably, the scores look a little better when 'retained meaning' and 'partial meaning loss' scores are added together. All Khanysisile's and Sbusiso's miscues led to a loss of meaning, even though the readers were reading texts below their grade levels. A likely explanation is that children have little access to English in the home, community and also in school. Often it is difficult to tell apart miscues from ordinary language errors because young readers with little access to English produce both errors and miscues in their developmental path towards English L2 proficiency. Example 6 below illustrates this.

\section{Example 6:}

\section{Mihlali, a grade 5 , reading a grade 5 English text}

Original text: When Martin Luther King, Jr., was a boy, many laws would not allow black people to go to the same places as whites. Some people thought blacks were not as good as whites. 
Reader's text: When Matin King, Jr., was a boy, many lows would not allo black people to go to the same places as whities. Some people thought blacks were not as good and whites.

The proper noun /Martin/ read as /Matin/ probably is dialect pronunciation, rather than a miscue. Mihlali pronounced the word the same way throughout the text. / Laws/ read as /lows/ is not a straightforward case of a miscue. This word, like many words in English materials read by this group of readers in the course of this study, doesn't seem to be in Mihlali's oral or written vocabulary, raising the possibility that this is a genuine error rather than a miscue. /Thought/ read as/tot/ is definitely not a miscue because the voiceless dental/th/is produced as a voiceless alveolar/t/ by many isiXhosa-dominant users of English. Finally, the case of /whites/ read as /whities/ is also unclear if it is an error or deliberate use of a derogatory colloquial, which if it is, would qualify the word as a genuine miscue. The difficult-to-classify words in Example 6 show that these troublesome miscues can present to teachers and researchers as primarily graphophonic problems - as failures to use appropriate decoding strategies, whereas, in fact, the difficulties are primarily a function of the readers' underdeveloped knowledge of the relevant (oral and written) language and the lack of relevant background knowledge to make sense of the texts set before them.

\section{Graphophonic Miscues}

Table 6: Percentage of Miscues that have high graphophonics similarity with the Expected Response

\begin{tabular}{|l|c|c|c|c|c|c|c|}
\hline Language & $\begin{array}{c}\text { Khanyisile } \\
\text { Gr2 }\end{array}$ & $\begin{array}{c}\text { Sbusiso } \\
\text { Gr3 }\end{array}$ & $\begin{array}{c}\text { Nobuntu } \\
\text { Gr4 }\end{array}$ & $\begin{array}{c}\text { Mihlali } \\
\text { Gr5 }\end{array}$ & $\begin{array}{c}\text { Sindi } \\
\text { Gr6 }\end{array}$ & $\begin{array}{c}\text { Sisipho } \\
\text { Adult }\end{array}$ & $\begin{array}{c}\text { Ayanda } \\
\text { Adult }\end{array}$ \\
\hline isiXhosa & $97 \%$ & $92 \%$ & $86 \%$ & $100 \%$ & $95 \%$ & $95 \%$ & $90 \%$ \\
\hline English & $2(100 \%)$ & $4100 \%)$ & $92 \%$ & $98 \%$ & $96 \%$ & -- & -- \\
\hline
\end{tabular}

Table 6 shows that a high proportion of readers' miscues have graphophonic similarity to the original text. This is the case for child readers' isiXhosa and English miscues, and adult readers' miscues. Similarities between the young readers and adult proficient readers' use of the graphophonic system end here. Two things distinguish (adult) proficient readers' use of the graphophonic cueing system from less proficient readers. First, adult proficient readers are efficient in the ways in which they use knowledge of the graphophonic cueing system to read. Their word recognition/identification skills are automatic and their reading is fluent. Secondly, adult readers are adept at integrating their knowledge of graphophonics with grammatical and semantic cues to make sense of what they read. The child readers tend to rely heavily on just one of the cueing systems and, in almost all cases, the graphophonic cueing system. The child readers are often able to decode words, or more accurately, to re-code words - that is, to sound out words without understanding them and find it hard to convert graphophonic input into language (grammar) and/or meaning (Goodman, 1996). 
Tables 3, 5 and 6 show that over-reliance on graphophonic cues and minimal use of syntactic and semantic cues is strongly associated with 1) the least proficient reading (Khanysile and Sbusiso) and 2) the unfamiliar language of reading (English).

A high proportion of the readers' miscues are cued by graphophonics cues implying that the readers are heavily reliant on graphophonic cues (consider Table 7). Closer examination of the evidence suggests that even though readers are heavily reliant on graphophonic cues, the readers don't have a good command of isiXhosa graphophonics. The evidence comes from readers' reading rates. The reading rate is a measure of correct words per minute (CWPM). Reading speed indicates two things: a reader's word recognition skills and a reader's ability to create meaning of what is read at an acceptable rate (Caldwell \& Leslie, 2009, p. 97). The young readers' isiXhosa reading rates are presented in Table 7 below. Columns 2 to 6 presents reading rates of child readers and Column 7 and 8 reading rates of the adults, for purposes of comparison. The child readers reading rates are well below those of the adults and the groups' reading rates do not improve as readers move up the grades. Having listened to the readers slow, choppy and laboured oral reading (Rasinski, 2002, p. 93), the suggestion is that part of the problem is that readers' isiXhosa word recognition skills are poorly developed and that this undermines readers' ability to get efficiently to the meaning of what they read.

Table 7: Young Readers and Adult Readers isiXhosa Reading Rates

\begin{tabular}{|l|c|c|c|c|c|c|c|}
\hline \multicolumn{1}{|c|}{$\mathbf{1}$} & $\mathbf{2}$ & $\mathbf{3}$ & $\mathbf{4}$ & $\mathbf{5}$ & $\mathbf{6}$ & $\mathbf{7}$ & $\mathbf{8}$ \\
\hline $\begin{array}{c}\text { Text } \\
\text { Level }\end{array}$ & $\begin{array}{c}\text { Khanyisile } \\
\text { Gr2 }\end{array}$ & $\begin{array}{c}\text { Sbusiso } \\
\text { Gr3 }\end{array}$ & $\begin{array}{c}\text { Nobuntu } \\
\text { Gr4 }\end{array}$ & $\begin{array}{c}\text { Mihlali } \\
\text { Gr5 }\end{array}$ & $\begin{array}{c}\text { Sindi } \\
\text { Gr6 }\end{array}$ & $\begin{array}{c}\text { Sisipho } \\
\text { Adult }\end{array}$ & $\begin{array}{c}\text { Ayanda } \\
\text { Adult }\end{array}$ \\
\hline Grade 2 & 9 & 15 & & & & 88 & 69 \\
\hline Grade 3 & -15 & 1 & 35 & & & 75 & 78 \\
\hline Grade 4 & & & 15 & 12 & -6 & 79 & 65 \\
\hline Grades 5/6 & & & & 12 & 8 & 67 & 43 \\
\hline
\end{tabular}

\section{Discussion}

\section{Do readers' miscues retain grammaticality in isiXhosa (L1) and English (L2)?}

Readers' miscues retain grammaticality of text significantly better in isiXhosa than in English. This supports the claim that it is comparatively easier for readers to invoke and use knowledge of language - of grammar in particular - to read in a familiar language (isiXhosa/L1) than an unfamiliar language (English/L2). Keeping track of 'well-formedness' of texts during reading is a necessary but not sufficient condition to making meaning. Motivation and other cognitive abilities influence meaning making (comprehension) (Rand Study Group, 2004).

Differences of the effect of miscues on the grammar of isiXhosa and English should not be overstated because, for example, between $19 \%$ and $58 \%$ of readers' isiXhosa 
miscues are grammatical non-sense. Readers are not fully exploiting their superior oral language proficiency in isiXhosa to acquire discrete language skills and academic proficiency in isiXhosa (Cummins, 2003). A likely explanation is school language and literacy practices that do not encourage reading for meaning and a literacy curriculum that doesn't teach explicit reading comprehension skills (Nel, 2011).

In terms of cross-linguistic transfer, the data suggests that because readers have minimal discrete language skills and academic languag proficiency in isiXhosa (L1), very little of what they have learned in isiXhosa (L1) is usefully transferrable to English (L2) reading. In fact, likely is that readers are transferring poor reading habits from the $\mathrm{L} 1$ to the $L 2$, like the practice of treating text as grammatical and semantic non-sense. Useful transfer from $L 2$ to $L 1$ is even less likely.

\section{Do readers miscues retain textual meaning (are the readers' miscues semantically acceptable?) in the L1 and L2}

Readers' miscues retain meaning in isiXhosa better than English. This supports the suggestion that readers are 'better' able to use their background knowledge, word meanings and contextual knowledge to figure out what they are reading if it is a language they are familiar with.

A qualification is necessary here too. IsiXhosa miscues that retain meaning are lower than isiXhosa miscues that retain grammar, suggesting that while readers are relatively more 'successful' at keeping track of grammaticality of isiXhosa texts, they are less successful at keeping track of meaning, or at linking grammatical sense to semantic sense. On the other hand, superficial English language knowledge, as indexed by low grammatical miscues, doesn't mean readers are able to keep track of meaning.

Due to typographical/structural and orthographic differences between isiXhosa and English and the different contexts in which each of these languages is learned and used, makes it hard for readers to transfer vocabulary, background or contextual knowledge from isiXhosa to English, or vice versa.

\section{Do readers' miscues have high graphophonic similarity to the text in the L1 and L2?}

Readers' miscues have high graphophonic similarity to the text in isiXhosa and in English. The suggestion is that readers are, in fact, paying very close attention to the visual and phonic aspects of reading. Additional evidence in support of this interpretation is that readers' word accuracy rates are generally high in both languages. The challenge is not that the readers pay no attention to graphophonics or are careless in their use of phonics, but that they read too slowly because their word reading strategies are not efficient in part because they are not reading regularly texts at their instructional or independent reading levels. 


\section{Are readers using all three cueing systems in an effective manner?}

The readers are not using the three cueing systems in an effective manner. The readers are not involved with their reading, treating it as a mechanical process in which markings on a page are translated into appropriate sound units. Readers struggle to link graphophonic, syntactic and semantic cues to create meaning during oral reading. The process of meaning making is short-circuited at all three levels of the language cueing system in both isiXhosa and English. The groups' possibility to grow their knowledge of isiXhosa and English via extensive reading (Krashen, 2003), for instance, is frustrated by underlying poor literacy skills. For English, in addition to poor literacy skills, the underlying lack of basic conversational fluency and access to competent child and adult L1 or L2 model users of English in everyday interpersonal communication makes it difficult for children to experience English language instruction as a 'meaning-full' activity. Pedagogical implications include 1) improving children's word identification strategies, 2) enriching children's language experiences (via reading and participating in authentic language activities), and 3) teaching strategies that can assist readers to develop self-monitoring strategies (Schwartz, 2002 [1997]) and behaviours to improve reading comprehension (Pretorius \& Lephalala, 2011).

\section{Conclusion}

The overall conclusions of this paper are that, (a) readers of this sample read better in isiXhosa than in English, (b) these readers are not reading as well as they could be reading in isiXhosa. (c) IsiXhosa reading difficulties appear to be related to poor teaching of literacy, while (d) English reading difficulties are related to both poor teaching of literacy and to low levels of language proficiency in English, which in turn is related to classroom practices but also independent of it. Language curriculum and pedagogy needs take advantage of the potential of isiXhosa to build foundational literacy skills and learning dispositions in children that can be transferred to English language learning and to content area learning taught through isiXhosa or English.

\section{References}

Adams, M.J.(1990). Beginning to read: Learning and thinking about print. Massachusetts: MIT Press

Alexander, P. \& Fox, E. (2004). A historical perspective on reading research and practice. In Robert R. Ruddell and Norman J. Unrau (Eds.). Theoretical Models and Processes of Reading ( $\left.5^{\text {th }} \mathrm{Ed}\right)$. Newark: Delaware: International Reading Association

Beatty, L. \& Care, E. (2009). Learning from their miscues: Differences across reading ability and text difficulty. Australian Journal of Language and literacy, Vol. 32, No. 3, pp. 226-244

Bourdieu, P. (1991). Language and symbolic power. Massachusetts: Polity Press

Braunger J. \& Lewis, J.P. (2006). Building a knowledge base in reading, (2 ${ }^{\text {nd }}$ Ed.) Newark, Delaware: International Reading Association 
Caldwell, J.S. \& Leslie, L. (2009). Intervention strategies to follow Informal Reading Inventory Assessment. Boston: Pearson

Chall, J.S. Jacobs, V.A. \& Baldwin, L.E. (1990). The reading crisis: Why poor children fall behind. Massachusetts: Harvard University Press

Cummins, J. (2003). Reading and the bilingual student: Fact and friction. In Gilbert G. Garcia (Ed.) English Language Learners: Reaching the Highest Level of English Literacy. Newark, Delaware: International Reading Association

Cummins, J. (2001). Language, power and pedagogy: Bilingual children in the crossfire. Clevedon: Multilingual Matters

Flurkey, A.D., Paulson, E.J. \& Goodman, K.S. (Eds.). (2008). Scientific Realism in Studies of Reading. New York: Lawrence Erlbaum Associates

Freeman, D. \& Freeman, Y. (2003). Teaching English learners to read: Learning or acquisition? In Gilbert G. Garcia(Ed.) English Language Learners: Reaching the Highest Level of English Literacy. Newark, Delaware: International Reading Association

Fries, P.H. (2008). Words, context, and meaning in reading. In Alan D. Flurkey, Eric J. Paulson and Kenneth S. Goodman (Eds.) Scientific Realism in Studies of Reading. New York: Lawrence Erlbaum Associates

Goodman, K.S. (2003 [2004]). Reading, writing, and written texts'. In Alan D. Flurkey and Jinnguo Xu. (Eds.) On the Revolution of Reading: Selected Writings of Kenneth S. Goodman. Portsmouth: Heinemann

Goodman, K.S. (2003 [1976]). Miscue analysis: Theory and reality in reading. In Alan D. Flurkey and Jinnguo Xu. 2003 (Eds.) On the Revolution of Reading: Selected Writings of Kenneth S. Goodman. Portsmouth: Heinemann

Goodman, K.S. (2003 [1975]). The reading process. In Alan D. Flurkey and Jinnguo Xu. 2003 (Eds.) On the Revolution of Reading: Selected Writings of Kenneth S. Goodman. Portsmouth: Heinemann

Goodman, K.S. (2003 [1967]). Word perception: Linguistic bases. In Alan D. Flurkey and Jinnguo Xu. 2003 (Eds.) On the Revolution of Reading: Selected Writings of Kenneth S. Goodman . Portsmouth: Heinemann

Goodman, K.S. (1996). Ken Goodman on Reading. Portsmouth: Heinemann

Goodman, K. S. (Ed.) (1979). Miscue analysis: Applications to reading instruction. Urbana, Illinois: National Council of Teachers of English Name of author and chapter title?

Goodman K.S. \& Goodman, Y.M. (2010). Learning to read: A comprehensive model. In Richard J. Meyer and Kathryn F. Whitmore (Eds.). Reclaiming Reading: Teachers, Students, Researchers Regaining Spaces for Thinking and Action. London: Routledge

Goodman K.S. \& Goodman, Y.M. (2004). To err is human: Learning about language processes. In Robert R. Ruddell and Norman J. Unrau (Eds.). Theoretical Models and Processes of Reading ( $5^{\text {th }}$ Ed.). Newark: Delaware: International Reading Association

Goodman, Y. Watson, D. \& Burke, C.L. (2005). Reading miscue inventory: From evaluation to instruction, ( $2^{\text {nd }}$ Ed.). New York: Richard C. Owen Publishers, Inc. 
Heugh, K. (2003). Language policy and democracy in South Africa: The prospects of equality within rights-based policy and planning. Doctoral Dissertation: Centre for Research on Bilingualism, Stockholm University

Krashen, S. (2003). Three roles for reading for minority-language children. In Gilbert G. Garcia (Ed.) English Language Learners: Reaching the Highest Level of English Literacy. Newark, Delaware: International Reading Association

Leslie, L. \& Caldwell, J. (2006). Qualitative Reading Inventory -4. Boston: Pearson Education Inc.

Marek, A.M. \& Edelsky, C. (Eds.) (1999). Reflections and connections: Essays in honour of Kenneth S. Goodman's influence on language education. New Jersey: Hampton Press, Inc.

Mashiya, N. (2011). isiZulu and English in KwaZulu-Natal rural schools: how teachers fear failure and opt for English. South African Journal of Childhood Education, Vol. 1, No. 1, pp.19-31

McKenna, M.C. \& Picard, M.C. (2006). 'Assessment: revisiting the role of miscue analysis in effective teaching'. The Reading Teacher, Vol. 60, No. 4, pp. 378-380

Mosenthal, P. (1976/1977). Bridge principles in an abridged reply to Goodman'. Reading Research Quarterly, Vol. 12, No. 4, pp. 586-603

Moustafa, M. (1997). Beyond traditional phonics: Research discoveries and reading instruction. Portsmouth: Heinemann

National Institute of Child Health and Human Development (NICHHD). (2000). Report of the National Reading Panel. Teaching children to read: An evidence-based assessment of the scientific research literature and its implications for reading instruction. (NIH Publication No. 00-4769). Washington, DC: U.S Government Printing Office

Nel, C. (2011). Classroom Assessment of Reading Comprehension: How are pre-service Foundation Phase teachers being trained? Per Linguam, 27 (2): 40-63

Pretorius, E.J. \& Lephalala, M. (2011). Reading comprehension in high poverty schools: how it should be taught and how well does it work? Per Linguam 27 (2): 1-24

Rand Study Group, (2004). A Research agenda for improving reading comprehension: RAND Reading Study Group. In Robert R. Ruddell and Norman J. Unrau (Eds.). Theoretical Models and Processes of Reading ( $5^{\text {th }}$ Ed.). Newark: Delaware: International Reading Association

Rasinski, T. (2002 [2000]). Speed does matter in reading. Evidence-based Reading Instruction: Putting the National Reading Panel Report into Practice. Newark: International Reading Association. pp. 91-96

Rosenblatt, L.M. (2004). The transactional theory of reading and writing. In Robert R. Ruddell and Norman J. Unrau (Eds.). Theoretical Models and Processes of Reading $\left(5^{\text {th }}\right.$ Ed.) Newark: Delaware: International Reading Association 
Schwartz, R.M. (2002 [1997]). Self-monitoring in beginning reading. Evidence-based Reading Instruction: Putting the National Reading Panel Report into Practice, Newark, Delaware: International Reading Association.

Sirin, S. (2005). Socioeconomic status and academic achievement: A meta-analytic review of research. Review of Educational Research, 75, 417-453

Stanovich, K.E. (2004). Matthew effects in reading: Some consequences of individual differences in the acquisition of literacy. In Robert R. Ruddell and Norman J. Unrau (Eds.). Theoretical Models and Processes of Reading ( $5^{\text {th }}$ Ed.). Newark: Delaware: International Reading Association

Stanovich, K.E. (2000). Progress in understanding reading: Scientific foundations and new frontiers. New York: The Guildford Press

Van der Berg, S. \& Burger, R. (2003). Education and socio-economic differentials: A study of school performance in the Western Cape. Development Policy Research Unit Working Paper 03/73. University of Cape Town

Wilde, S. (2000). Making miscue analysis easy: Building on students' strengths. Portsmouth: Heinemann

Wren, S. (2008). Reading and the three cueing systems. Southwest Educational Development Laboratory. Austin, Texas 